\title{
VIII.-Description of a new species of Veronica.
} By JoHn BaLL, M.R.I.A.

Several years ago I gathered upon the steep crags of the Pagna della Croce, one of the highest peaks of the Apuan Apennines, specimens of a Veronica which accidentally remained unexamined until the present year. Although resembling in many respects $V$. aphylla, L., my specimens differ in so many essential particulars, that I am induced to distinguish them by a specific name; and I subjoin a description of the proposed new species, together with that of $V$. aphylla, from which the diagnosis will more readily be made.

$V$. longistyla, nobis. Caule brevissimo, repente, cæspitoso, filiformi; foliis inferioribus minimis, superioribus subrosulatis, omnibus obovato-spathulatis, acutiusculis, grandiuscule crenato-serratis ; pedunculo scapiformi adscendente, vix pollicari, supra in pedicellos, 2-4 erectos, bracteis linearibus et capsulis 3-4 longiores, diviso ; corolla parva, filamentis styloque breviori; capsula matura late obcordata, profunde emarginata, calycem sesquilonga, stylo breviori, seminibus lentiformibus, albo-hyalinis, glabris. Herba tota pilis brevissimis articulatis, superne glandulosis, adspersa.

V. aphylla, L. Caule brevissimo cæspitoso; foliis rosulatis, late obovato-spathulatis, obtusis subintegerrimis ; pedunculo seapiformi erecto, 1-3 pollicari ; supra in pedicellos 2-4, bracteis capsulisque vix duplum longiores, diviso; corollæ segmentis latis, filamenta stylumque superantibus; capsula matura obovato-elliptica, sinu brevissimo emarginata, calyce et stylo duplum longiore; seminibus lentiformibus, luteis, glabris. Herba tota pilis articulatis, glandulosis, crebris, obtecta.

$V$. longistyla differs at first sight from V. aphylla in its smaller size, more slender habit, and in its less abundant and less glandular pubescence; but the most certain characters must be sought in the completely different shape and much smaller size of the capsule, and in the much greater length of the style, which is longer instead of being one-half shorter than the ripe capsule, as in $V$. aphylla. I have to call attention to the description of the capsule of $V$. aphylla given by Mr. Bentham in the tenth volume of the 'Prodromus.' It is there stated that the capsule is obcordate, and that eminent botanist, to whom I have submitted a specimen of $V$. longistyla, observes, "I do not find so much difference in the form of the capsule;" he however further observes, "I have but one specimen of $V$. aphylla in good fruit." I have gathered $V$. aphylla in fruit in Dauphiné, in the cantons of Berne, Glaris, Tessin, and Valais in Switzerland, in the Tyrol, and in several parts of the Carpathians, and with the specimens before me I do not find any difference in the form of the ripe fruit, which is as I have above 
described it, with a very slight notch at the summit, and by no means obcordate. The descriptions of other eminent authors are by no means concordant. According to Koch and Wahlenberg the capsule is obcordate; Bertoloni describes it as "subrotundata emarginata;" while Reichenbach says, "capsula obovato-triangulari, vix emarginata." I am disposed to believe that the Italian plant known to Bertoloni, and possibly also the specimen in good fruit preserved in Mr. Bentham's herbarium, may be $V$. longistyla, while the common alpine plant known to Reichenbach is the true $V$. aphylla.

The difference of habit and appearance between the plant here described and the ordinary $V$. aphylla might be referred to the peculiarity of its birthplace upon the arid marble rocks of the Carrara Apennines; but it would be a large concession to the views of those who most believe in the modifying influence of external conditions, to : uppose that they can so far change the form of the essential organs of vegetation as would be required if these plants be not specifically distinct.

Having lately received Corsican specimens of Veronica repens, Lois., from my friend M. Jordan of Lyons, I may remark that that plant appears to me to be a mere variety of $V$. serpyllifolia, L. It differs from the mountain form of that plant, known to the Scotch botanists as V. humifusa, Dicks., in no respect except in the somewhat more hairy segments of the calyx, and apparently in the leaves being rather more fleshy than in the Scotch plant.

\section{PROCEEDINGS OF LEARNED SOCIETIES.}

\section{ZOOLOGICAL SOCIETY.}

Jan. 9, 1849.-William Yarrell, Esq., Vice-President, in the Chair. The following papers were read:-

1. Descriptions of three new species of Delphinide. By J. E. Gray, Esq., F.R.S.

The species which form the subject of the present communication were collected by Dr. Dickie, R.N., during his voyage in the Pacific, and have been transferred by him to the British Museum.

\section{Delphinus Eutropia.}

Nose of skull rather longer than the length of the brain-cavity, rather dilated on the sides before the notch, very convex and rounded above; triangle elongate, produced before the tooth-line, concave on the sides, and strongly keeled in the centre behind; hinder edge of blow-hole rather prominent. Intermaxillar wide, convex above, leaving a rather broad open space in front. Palate rather concave in front, convex in the centre behind, the hinder part keeled on each side. 


\section{$2 \mathrm{BHL}$ Biodiversity Heritage Library}

Ball, John. 1850. "VIII.-Description of a new species of Veronica." The Annals and magazine of natural history; zoology, botany, and geology 5, 47-48. https://doi.org/10.1080/03745486009494882.

View This Item Online: https://www.biodiversitylibrary.org/item/61924

DOI: https://doi.org/10.1080/03745486009494882

Permalink: $\underline{\text { https://www.biodiversitylibrary.org/partpdf/58636 }}$

\section{Holding Institution}

University of Toronto - Gerstein Science Information Centre

\section{Sponsored by}

University of Toronto

\section{Copyright \& Reuse}

Copyright Status: NOT_IN_COPYRIGHT

This document was created from content at the Biodiversity Heritage Library, the world's largest open access digital library for biodiversity literature and archives. Visit BHL at https://www.biodiversitylibrary.org. 